Meta

Journal des traducteurs

Translators' Journal

\title{
Translation Quality: a Housian Analysis
}

\section{Sara Viola Rodrigues}

Volume 41, numéro 2, juin 1996

Traduction et terminologie au Brésil

Translation and Terminology in Brazil

URI : https://id.erudit.org/iderudit/003969ar

DOI : https://doi.org/10.7202/003969ar

Aller au sommaire du numéro

Éditeur(s)

Les Presses de l'Université de Montréal

ISSN

0026-0452 (imprimé)

1492-1421 (numérique)

Découvrir la revue

Citer cet article

Rodrigues, S. V. (1996). Translation Quality: a Housian Analysis. Meta, 41(2), 223-227. https://doi.org/10.7202/003969ar

\section{Résumé de l'article}

L'auteur examine un modèle d'évaluation de la qualité de la traduction. Il affirme que ce modèle, créé en ¡981 par Juliane House, est encore le meilleurs disponible pour une évaluation qualitative des traductions et qu'il représente un progrès immense par rapport aux modèles précédents d'utilisation que vous pouvez consulter en ligne.

https://apropos.erudit.org/fr/usagers/politique-dutilisation/ 


\section{TRANSLATION QUALITY: A HOUSIAN ANALYSIS}

SARA VIOLA RODRIGUES

Federal University of Rio Grande do Sul, Porto Alegre, Brazil

Résumé

L'auteur examine un modèle d'évaluation de la qualité de la traduction. Il affirme que ce modèle, créé en 1981 par Juliane House, est encore le meilleurs disponible pour une évaluation qualitative des traductions et qu'il représente un progrès immense par rapport aux modèles précédents

Abstract

The author comments on the translation quality assessment model developed by Juliane House and published in 1981. Although it is somewhat dated, this model has given the best results so far, and is a definite improvement over its predecessors.

In recent years there has been a significant increase in interest in developing good criteria for solving the problems of assessing the quality of translation.

This interest has resulted in many studies concerning both the nature of translation, and the techniques and procedures used in the translation process. There have also been attempts to build models for assessing translation quality which may be used as workable tools by translators and translation evaluators.

In this article I shall comment on the model developed by Juliane House for assessing translation quality. In spite of the fact that the model was published in 1981, it seems to be the best model available for making the final qualitative judgement of a translated text, as it represents a considerable improvement over earlier treatment of this aspect of translation.

According to House, translation quality assessment studies fall into three categories: firstly, there are pre-linguistic studies in which vague and subjective statements of translation quality are the norm - e.g., Savory's list of principles for a translation of optimal value; secondly, there are psycholinguistic studies in which translation quality is judged in terms of the effect a translation should have on the receptor - in this regard, Nida and Taber are the reseachers most cited by Brazilian scholars working on translation theory; thirdly, there are source-text-based studies which attempt to build linguistic-based criteria to describe both the source-text and the target-text.

Interested in the theoretical understanding of the process of translation, but principally in solving the practical problems of describing and assessing translations as finished products, House establishes the inadequacy of pre-linguistic and psycholinguistic studies on the basis that they do not provide a norm against which the results of any translation can be measured. The author goes beyond the pragmatic models developed by Koller (1974) and Reiss (1968, 1971a,b, 1973) and develops a comprehensive linguistic model of translation quality assessment, which includes eight situational-contextual dimensions based on Crystal and Davy's system (1969), in addition to linguistic correlates. ${ }^{1}$

House's model makes it possible to analyze the source text (ST) and evaluate the translated text (TT), taking into consideration the main situational functional characteristics of the ST. 
House (1981: 49) affirms that "the function of a text which should be kept equivalent if a translation is to be adequate, can be determined by 'opening up' the linguistic materials in terms of the [...] set of extralinguistic, situational constraints." This linguistic evidence is divided into three types: syntactic, lexical and textual.

House then suggests that a linguistic analysis of the text itself is the element that links the author's intention and the receptor's response (i.e., the reader's reaction). Of these three elements (autor's intention, receptor's response and the text itself), the text is the only one opened to an objective investigation. House draws on Dressler's definition of a text as "any stretch of language in which the individual components all relate to one another and form a cohesive whole" (1981: 29). She then points out that the textual aspect of meaning is given by the particularities of text constitution, namely the way co-textual references are given expression in the occurrence of anaphoras, substitutions, pro-forms, ellipses, co-references, and so on.

The two other aspects of meaning that are present in any text and should be kept equivalent in an adequate translation are semantic and pragmatic elements.

House adopts Halliday's (1970a,b, 1971, 1973) ideational and interpersonal categories of language functions to help in the selection and classification of texts for analysis. ${ }^{2}$ Her textual typology is based on the predominant language function of texts.

House applied her model on a corpus of eight German and English textual pairs (STs and TTs). The results of this study were presented in her Ph.D. dissertation, which was later published as a book.

I have tested Juliane House's model on ideational and interpersonal English sourcetexts translated into Portuguese from a wide range of provinces. The effectiveness of the model was shown by my results, especially those concerning covertly erroneous errors, which is any mismatch along the situational dimensions of the Housian model - a good number of such errors would not be detached by the translator if it were not for the illuminating help of the model. The application of the Housian model demands a more subtle and careful reading of the text in order to describe it $v i s-\grave{a}$-vis all eight situational dimensions.

House created a translation typology, which she considered more relevant to the translator than the text typology itself. In other words, it is not so important to know what kinds of source texts we are handling; but, it is essential to know what kind of translation a given source text calls for. According to House, there are two basic translation types: overt translation and covert translation.

In the case of overt translation, the TT is overtly a translation and not, as it were, a second original; the ST is tied to the source language community and culture; the ST is specifically aimed at source language addressees, but it may also be aimed at other addressees because of the potential general human interest it may generate. Such sourcetexts may be subdivided into two types:

a. overt, historically linked STS (e.g., political discourse): non-fictional texts linked to particular historical facts; texts aimed at specific source receptors;

b. overt, timeless $S T$ : fictional texts transcending a particular historical meaning, nevertheless exhibiting language user dimensions.

The analysis of both historically linked STS and overt timeless STs brings an important modification to House's model. In these two cases, it is not possible to achieve a direct match of the original ST function; the translator must try a second level function: "the one holding not only for the contemporary, educated middle class native speakers of the target culture, but also for their potential counterparts in the source culture who are not the original addressees." House (1981: 191). 
As regards non-fictional texts that are not specifically linked to the source culture nor directed at particular addressees, they necessitate covert translation. For example, the potential pragmatic meaning of a scientific text about coronary artery disease is virtually the same for scientists in any part of the world.

To verify the practical value of House's translation typology referred to above, I selected "The Me Decade And The Third Great Awakening" — one of the essays in Tom Wolfe's The Purple Decades, published in the United States in 1982 - as the ST. As far as the TT is concerned, I chose Luiz Fernando Brandão's version, published by LPM, Brazil, in 1989.

Because of constraints on the length of this article, the analysis of the Housian model of linguistic-situational features of STs and TTs will not be further elaborated on here.

My analysis revealed the textual function of Wolfe's essay, which may be summed up in the following way: the addresser's intention is to write about social aspects of life in America from the sixties to the early eighties. In an ironic tone he focuses on fanatical sects characterized by holy-rolling and other non-rational practices, the Scientology movement, the psychedelic or hippie communes of the 1960's, gay power, lemon sessions, drugs, sex and secularized religion - all of it with a view to capturing the fabled "Spirit of the Age." Wolfe suggests that the ways of salvation chosen by Americans in the sixties are ridiculous, superficial and spurious - a sheer waste of human energy.

A great number of references to American places, facts and characters mark this text as strongly linked to the source language, community and culture. There can be no doubt that the original addressees are the American people. Thus, according to Juliane House's theory, this text falls within the category of STs necessitating overt translation. The analysis of the TT, however, reveals that the translator chose - perhaps unconsciously - a covert type of translation. The first piece of evidence of this appears in the treatment given to the subject matter of the essay title itself: the translator makes no reference whatsoever to the religious meaning of Awakening (Despertar). It is true that near the end of the essay the author presents a historical explanation of the religious phenomenon of The Great Awakening within the body of the text, but it seems that a brief footnote at the very beginning of the translated essay would have helped the naive reader to grasp the special meaning of this expression in American culture.

The translator did not take into consideration the need to add a second-level function to the TT. In other words, he took the pragmatic meaning of the ST and TT as being one and the same: he assumed the message would be equally received and understood by both American and Brazilian receptors. In fact, he does not introduce in the TT any explanation about social facts, characters or typical aspects of the source-culture which are manifest in the ST. If it were not for a footnote in the original saying that the text was first published in an American magazine, for the introduction which presents Wolfe as a great American postwar writer, an exponent of the New Journalism, and for the name of the translator on the title page, the TT could be considered as a second original.

My hypothesis is that the translator attempted to provide readers with a fluent reading experience. To this end, he avoided footnotes, explanatory parentheses, as well as information about the socio-cultural American context. It should be noted that it is sometimes difficult to determine when such aids are really necessary when we consider that American and Brazilian cultures are closely related.

The consequence of the translator's option for a covert type of translation - which disregarded the procedures referred to earlier - is the occurrence of covertly erroneus errors which, as stated above, are mismatches of situational dimensions. The translator of this essay thus violates the strongly marked interpersonal function of the source text. 
A typical example of this type of error can be found on pages 269 (TS) and 345 (TT) in the treatment of the subtitle The holy roll. This expression, as inferred by the ST, refers to a non-rational, frantic religious practice taking place during the services of some fanatical sects. The title was translated as beatério, a Portuguese word which is defined in The New Michaelis Illustrated Dictionary as: "1. pious people. 2. their religious practices. 3. bigotry, hypocrisy." (1968: 160). Having a broader semantic and pragmatic meaning, beatério does not convey the same meaning as The holy roll. Moreover, beatério has a very restricted use in Brazilian Portuguese. Perhaps beataria would have been a better choice, since it is more frequent in speech and has a derogatory connotation closer to the intended meaning of the ST. The translator should perhaps have used a footnote reference in The holy roll, to clear up such a culture-specific term, thus avoiding the consequent mismatch, which detracts from the textual function of the target text.

The advantage of knowing House's model, then is that besides illuminating the translator's mental operation, it sheds more light on the problematic area of the situational dimensions of a text, pointing to the need for careful choice of lexical items adequate to the text's special topics or province.

It is quite clear that the translator of the essay failed to choose adequate lexical items when dealing with the topic of religion, one of the aspects of the essay province. For example, Bleeding Heart of Jesus (p. 269) was translated as Coração Aquecido de Jesus (p. 345), instead of the popularly coined Sagrado Coração de Jesus or, simply, Coração de Jesus. In this case two errors were committed: the covertly erroneous error - as explained above - and the overtly erroneus error, namely a denotative mismatch in the translation of bleeding.

Another good example of a subheading translation that is not equivalent to the ST is the case of Young faith, aging groupies (p. 280). On the one hand, the corresponding translation Jovens carolas, coroas avançados (p. 280) is inadequate because carolas has a derogatory meaning which does not necessarily correspond to the meaning of faith in the original. According to The New Michaelis Illustrated Dictionary (1968: 249), carola stands for "1. man with a tonsurelike bold spot on the head. 2. very pious person, pietist, religionist, devotee." On the other hand, aging groupies hardly corresponds to coroas avançados. According to Webster's New Collegiate Dictionary (1981: 503), Groupie refers to "a female fan of a rock group who usually follows the group around on concert tours." Coroas avançados is a wrong choice, first, because it does not have an equivalent meaning to the one cited above. Second, the Portuguese phrase lacks the meaning component of "being part of a group following their idols," and therefore the TT subheading does not convey the image of priests and preachers appearing in secularized marches, carrying placards, for the sole purpose, according to the author himself, of luring young people back to the church. (A fé jovem $e$ as veteranas tietes would have been more appropriate.)

It might be concluded that Wolfe's essay would have been better translated if it had been treated as an overt type of translation, which would have facilitated the complex task of transferring the TS socio-cultural aspects to the TT.

Of course, as House herself stated, the main difficulty of an overt translation is the dialectical tension that arises when the translator is in the process of choosing what textual elements to keep and what elements to change in order to add a second-level function to the text. Despite these difficulties, linguists, translation teachers and translators should endeavour to learn and test models and translation typologies so that their task of translating or evaluating translation might benefit from the insights such theorectical and practical research provides. 
Notes

1. House's model is used for establishing functional equivalence. According to Lyons (apud House 1981: 37), "the function of a text is the application or use which the text has in the particular context of a situation". In order to determine the source text's function, it is necessary to break down the situation in which the text is embedded into more specefic and manageable parts: the situational dimensions.

House divided the category of situational dimensions into two sections: dimensions of language user and dimensions of language use. For each section the author used the following subcategories: DIMENSIONS OF LANGUAGE USER:

a. Geographical Origin - features which mark a text producer's geographical origin.

b. Social Class - features which mark a text producer's position on a social scale.

c. Time - features which provide clues to a text's temporal provenance.

DIMENSIONS OF LANGUAGE USE:

a. Medium: simple/complex - text-specefic features of spoken and/or written language.

b. Participation: simple/complex - features which elicit the text producer's participation, as well as the "indirect addressee's participation.

c. Social Role Relationship - features which mark the role relationships between the addresser and the addressees.

d. Social Attitude - features which elicit the degrees of social distance or proximity between the addresser and the addressees.

e. Province - features which reflect occupational and professional activity, the field or topic of the text and details of text production.

(Adapted from House 1985: 37-50)

2. The terms ideational and interpersonal are labels for the referential and non-referential functional components of language.

\section{REFERENCES}

CRYSTAL, D. and D. DAVY (1969): Investigating English Style, London, Longman.

DRESSLER, W. (1972): Einfuhrung in die Textlinguistik, Tübingen, Niemeyer.

HALLIDAY, M. A. K. (1970a): "Language Structure and Language Function", New Horizons in Linguistics, Harmondsworth, Penguin, pp. 140-165.

HALLIDAY, M. A. K. (1970b): "Functional Diversity in Language as Seen from a Consideration of Modality and Mood in English", Foundations of Language, 6, pp. 322-361.

HALLIDAY, M. A. K. (1971): "Linguistic Function and Literary Style", Literary Style: A Symposium, London, Oxford University Press, pp. 330-368.

HALLIDAY, M. A. K. (1973): Explorations in the Functions of Language, London, Arnold.

HOUSE, Juliane (1981): A Model for Translation Quality Assessment, Tübingen, Narr.

KOLLER, W. (1974): “Anmerkungen zu Definitionen des Übersetzungs 'vorgangs' und der Übersetzungskritik", Aspekte der theoretischen, sprachenpaarbezogenen und angewandten Sprachwissenschaft, Heidelberg, Groos, pp. 35-45.

NIDA, E. A. (1964): Toward a Science of Translating, Leinden, Brill.

NIDA, E. A. and C. R. TABER (1969): The Theory and Practice of Translation.

REISS, K. (1968): "Überlegungen zu einer Theorie der Übersetzungskritik", Linguistica Antverpiensia, 2, pp. 369-383.

REISS, K. (1971a): "Die Bedeutung von Texttyp und Textfunction fur den Übersetzungsprozess", Linguistica Antverpiensia, 5, 137-148.

REISS, K. (1971b): Möglichkeiten und Grenzen der Übersetzungskritik, München, Hueber

REISS, K. (1973): "Der Texttyp als Ansatzpunkt fur die Losung von Übersetzungproblemen", Linguistica Antverpiensia, 7, pp. 111-127.

RODRIGUES, Sara V. (1985): A Avaliação da Tradução: Aplicação do Modelo de Juliane House a Textos Traduzidos do Inglês para o Português, Diss., Porto Alegre, PUCRS.

SAVORY, T. (1968): The Art of Translation, Boston, The Writer.

The New Michaelis Illustrated Dictionary (1968): Ediçoes Melhoramentos, São Paulo, Brazil and F. A. Brockhaus, Wiesbaden, Germany, 5th ed.

Webster's New Collegiate Dictionary (1981): Springfield, G. \& C. Merriam Co.

WOLFE, Tom (1984): "The Me Decade And The Third Great Awakening", The Purple Decades, Harmondsworth, Penguin.

WOLFE, Tom (1989): "A Década do Eu e o Terceiro Grande Despertar", Décadas Púrpuras, Transl. by Luiz F. Brandão, Porto Alegre, LPM. 